\title{
Carbonate laminae recorded in a siliciclastic tidal flat colonized by microbial mats
}

\author{
Lucía Maisano $^{\mathrm{a}, \mathrm{b}, *}$, I. Emma Quijada c , Diana G. Cuadrado ${ }^{\mathrm{a}, \mathrm{b}}$, Vanesa Liliana Perillo ${ }^{\mathrm{a}, \mathrm{d}}$, \\ Jerónimo Pan ${ }^{\text {e,f }}$, Ana María Martinez ${ }^{\mathrm{g}}$
}

a Instituto Argentino de Oceanografia (IADO-CONICET-UNS), Florida 5000, 8000 Bahía Blanca, Buenos Aires, Argentina

b Departamento de Geología, Universidad Nacional del Sur, Av. Alem 1253, 8000 Bahía Blanca, Buenos Aires, Argentina

c Departamento de Geología, Universidad de Oviedo, C/ Jesús Arias de Velasco s/n, 33005 Oviedo, Spain

d Departamento de Biología, Bioquímica y Farmacia, Universidad Nacional del Sur, San Juan 670, 8000 Bahía Blanca, Buenos Aires, Argentina

e Instituto de Geología de Costas y del Cuaternario (IGCyC- UNMdP-CONICET), Funes 3350, 7600 Mar del Plata, Buenos Aires, Argentina

${ }^{\mathrm{f}}$ Instituto de Investigaciones Marinas y Costeras (IIMYC-CONICET), 7600 Mar del Plata, Buenos Aires, Argentina

' Departamento de Química, Universidad Nacional del Sur, Av. Alem 1253, 8000 Bahía Blanca, Argentina

\section{A R T I C L E I N F O}

\section{Article history:}

Received 10 April 2020

Received in revised form 27 May 2020

Accepted 28 May 2020

Available online 03 June 2020

Editor: Dr. J. Knight

\section{Keywords:}

Evaporation

Hydrodynamics

Saline basin

Micrite

Progradational environment

\begin{abstract}
A B S T R A C T
Microbial mats in siliciclastic coastal environments are considered as non-lithifying systems that lack the potential for calcification. This work documents precipitation and preservation of well-defined, laterally continuous carbonate laminae in low-relief microbial mats from a siliciclastic supratidal flat in northern Patagonia (Paso Seco, Argentina). Petrographic, epifluorescence, and SEM-EDS studies of surficial and buried microbial mats show that they are composed of repeated sediment sequences comprised of four different types of laminae, which are, from base to top: (A) a sand and silt lamina, (B) a lamina largely composed of organic matter displaying moulds of subvertical cyanobacteria filaments, (C) a lamina composed of dense micritic carbonate, which is cut by moulds of vertical cyanobacteria filaments, and (D) a lamina composed of organic matter containing abundant horizontal cyanobacteria filaments. The formation of each different lamina is strongly controlled by the environmental conditions, characterized by episodic seawater flooding, followed by several days to weeks in which water remains covering the sediment and gradually evaporates producing a salinity increase and the precipitation of calcite, gypsum and halite. Thus, the basal sand and silt lamina forms as the result of the transport of siliciclastic grains and particles during seawater flooding. The overlying lamina B, composed of organic matter with moulds of subvertical cyanobacteria filaments, is formed when calm water conditions are recovered and organic material is produced by photosynthetic microbial activity. The following lamina $\mathrm{C}$, composed of dense micritic carbonate, precipitates when the salinity of stagnant water reaches $\mathrm{CaCO}_{3}$ supersaturation. Finally, the uppermost lamina D, composed of organic matter with horizontal cyanobacteria filaments, is developed while the sediment surface is drying and gypsum and halite precipitate, although these minerals are not preserved in the sediment because they dissolve during subsequent inundations. All these observations show that welldeveloped, laterally-continuous carbonate laminae may be formed and preserved in a siliciclastic tidal environment if biotic and abiotic sedimentary processes closely interact to create the required conditions. The studied microbial mats increase sediment impermeability, which favours water retention in the flat and, thus, subsequent evaporation of the retained seawater. Moreover, microbial cells and EPS (extracellular polymeric substance) suspended in seawater might act as nuclei for $\mathrm{CaCO}_{3}$ precipitation, which will later settle down on the microbial mat. In addition, EPS of the microbial mats may also serve as nucleus for in situ carbonate precipitation.
\end{abstract}

(c) 2020 Elsevier B.V. All rights reserved.

\section{Introduction}

Geological studies on microbial mats have been traditionally marked by two different approaches: some researchers focus on carbonate three-dimensional microbial mats and others focus on siliciclastic two

\footnotetext{
* Corresponding author at: IADO-CONICET-UNS, 8000 Bahía Blanca, Argentina.

E-mail address: lmaisano@iado-conicet.gob.ar (L. Maisano).
}

dimensional microbial mats (Noffke and Awramik, 2013). These divisions are motivated on the existence of a large group of calcifying microbialites, which commonly show three-dimensional structures and are typically developed in predominantly carbonate settings, and another group of low-relief, poorly/non-calcified microbial mats, which are typical in siliciclastic intertidal and supratidal environments (Riding, 2011a, 2011b; Noffke and Awramik, 2013). These different approaches have traditionally conditioned studies on present-day and 
fossil microbial deposits, largely envisioning sedimentary environments colonized by microbial mats as functioning differently depending on their siliciclastic or carbonate character. However, this division is not straightforward in all cases, but there are sedimentary environments in which both overlap, as is the case in the environment presented in this work.

Microbial mat calcification has been intensively studied in calcifying microbialites (e.g., Burne and Moore, 1987; Douglas and Beveridge, 1998; Riding, 2000; Paerl et al., 2001; Kaźmierczak et al., 2004; Dupraz and Vissher, 2005; Altermann et al., 2006; Benzerara et al., 2006; Stal, 2012), and several models for carbonate precipitation have been proposed, ranging from entirely microbial to chemicallymediated mechanisms (Demicco and Hardie, 1994; Douglas and Beveridge, 1998; Dupraz and Vissher, 2005). Microbial processes favouring carbonate precipitation include metabolic and geochemical processes that induce alkalization of the microenvironment around the bacteria cells (see Riding, 2000; Visscher and Stolz, 2005; Dupraz et al., 2009), such as photosynthesis (Défarge et al., 1994; Arp et al., 2001; Ludwig et al., 2005) or sulphate reduction (Berner, 1985; Chafetz and Buczynski, 1992; Reid et al., 2000). Moreover, microorganisms provide nucleation sites that may help overcome the activation energy necessary to begin carbonate precipitation (Burne and Moore, 1987; Défarge et al., 1996; Visscher and Stolz, 2005; Dupraz et al., 2009). These nucleation sites may be the extracellular polymeric substances -EPS- (Bhaskar and Bhosle, 2005), cyanobacteria sheaths (Burne and Moore, 1987; Pentecost and Bauld, 1988; Défarge et al., 1994), or even the bacteria cells themselves (Achal et al., 2010). On the other hand, physicochemical processes in the macro-environment may produce favourable conditions (high $\mathrm{Ca}^{2+}$ concentration, $\mathrm{pH}$, and alkalinity) for carbonate precipitation (Dupraz and Vissher, 2005; Dupraz et al., 2009). In fact, purely chemically-mediated mechanisms have also been described for carbonate precipitation within some microbial mats developed in increased alkaline environments (Arp et al., 2003).

Some low-relief microbial mats in muddy-sandy intertidal and supratidal environments create the physicochemical conditions necessary for carbonate precipitation and they carry out metabolic and geochemical processes that might induce carbonate precipitation. However, the reported examples of this type of mats in the literature are generally poorly lithified (Riding, 2011a, 2011b; Noffke and Awramik, 2013), and most of the intertidal-supratidal mats in which carbonate precipitation has been documented are from predominantly carbonate sedimentary environments, such as the tidal flats of northwestern Andros Island, Bahamas (Monty, 1967; Shinn et al., 1969; Hardie and Ginsburg, 1977) and the tidal flats of Abu Dhabi, Arabian Gulf (Kinsman and Park, 1976; Bontognali et al., 2010; Strohmenger et al., 2011). To the best of our knowledge, there is only one example in the literature of calcium carbonate precipitates in microbial mats developed on a siliciclastic coastal environment, the sandy beaches of Schiermonnikoog Island in the North Sea (the Netherlands), studied by Kremer et al. (2008). They documented the carbonate precipitates in uneven layers distributed in young and developing mats.

To re-evaluate the siliciclastic coastal microbial mats as nonlithifying systems that lack the potential for calcification, the present study documents a new example of calcium carbonate precipitation in microbial mats from a siliciclastic coastal environment from northern Patagonia (Paso Seco, Argentina). The present research documents well-defined, laterally continuous carbonate laminae in surficial microbial mats. Furthermore, these laminae are also preserved in buried microbial mats several centimetres below the surface, which highlights their preservation potential and their contribution to sediment accretion. The results of this study provide insights into the environmental conditions for carbonate microbial mat formation, highlighting the changing water chemistry that favours the precipitation of calcium carbonate within siliciclastic coastal environments in the presence of microbial mats. Finally, a plausible explanation for the mechanisms of carbonate precipitation in this environment is suggested, trying to span the role of biotic influence in abiotic sedimentary processes.

\section{Study area}

\subsection{Climatic and geomorphologic setting}

The study area, Paso Seco, is a temperate coastal flat in southern Buenos Aires province $\left(40^{\circ} 33^{\prime} \mathrm{S} ; 62^{\circ} 14^{\prime} \mathrm{W}\right)$ (Fig. 1a). The climate is classified as semiarid, according to the climatic classification of the Argentinian Pampas proposed by Aliaga et al. (2017), and is characterized by an average annual rainfall of $<300 \mathrm{~mm}$ and a potential evapotranspiration that commonly exceeds precipitation (Ferrelli et al., 2012). Therefore, the aridity is marked enough as to limit vegetation development. The average minimum and maximum temperatures range between 14 and $30{ }^{\circ} \mathrm{C}$ in summer, and from 2 to $12{ }^{\circ} \mathrm{C}$ in winter.

Paso Seco is located in a mesotidal coast where mean and maximum tidal ranges are $1.62 \mathrm{~m}$ and $2.5 \mathrm{~m}$, respectively. Geomorphologically, the area was originally a late Holocene tidal channel that was obstructed by a sand spit (1.8 km wide) formed by NE longshore sediment transport along the coast (Fig. 1b). Consequently, shoreline migration towards the sea developed a progradational environment $>100$ years ago (Espinosa and Isla, 2011). Behind the sand spit, a semi-closed basin of $3.5 \times 0.4 \mathrm{~km}$ was developed (Fig. 1a), which is sporadically flooded during storm surges (Stempels Bautista, 2019) when seawater breaches the sand spit. Moreover, the landward area of Paso Seco coastal flat is connected to a tidal channel, which outflows at the north (Fig. 1a). On occasions, when the flat is subaerially exposed after flooding during warm periods, evaporites are present as a consequence of high temperatures and evaporation. This fact makes Paso Seco a saline-like basin (Perillo et al., 2019).

\subsection{Colonizing microbial mats}

Episodic flooding of the coastal flat favours sediment colonization by flat, $\approx 1 \mathrm{~cm}$-thick epibenthic mats, which are developed in the uppermost centimetre of the sediment. The arrangement of benthic microorganisms in these microbial mats follows a vertical stratification pattern, with representatives of the three domains of life on Earth, namely archaea, cyanobacteria and other free-living bacteria, and diatoms. Due to the hypersaline conditions that the sediments reach, these mats are largely devoid of metazoans and bioturbation, with only a few micronematodes and coleopterans exploiting the mats as a niche (see Garrett, 1970). Filamentous cyanobacteria in the order Oscillatoriales are by far the dominant members of the microbial consortium, with Microcoleus chthonoplastes being the most abundant species (Cuadrado and Pan, 2018). Regarding other components of the microphytobenthic community, pennate diatoms are well-represented. The metabolism of these microbes is characterized by the exudation of large amounts of EPS as an immediate response to rapid changes in osmotic pressure caused by variations in salinity or temperature during aerial exposure, which protects the community (Stal, 2012). EPS also aid in microbial locomotion and attachment to solid surfaces. Furthermore, the exudation of large amounts of EPS confers a slippery appearance to the mat surface and modifies the physical properties of the sediment, which, coupled with the particular hydrodynamics of Paso Seco, produces characteristic microbially-induced sedimentary structures (Maisano et al., 2019; Pan et al., 2019).

\section{Methods}

Water level fluctuations within the coastal flat were measured from May 2015 to present by placing a HOBO water level logger (model U20) $40 \mathrm{~cm}$ below the flat surface (Fig. 1b). The sensor continuously records water level and water temperature every $10 \mathrm{~min}$. In September 2017, six water samples were taken from the study area, one from a tidal 

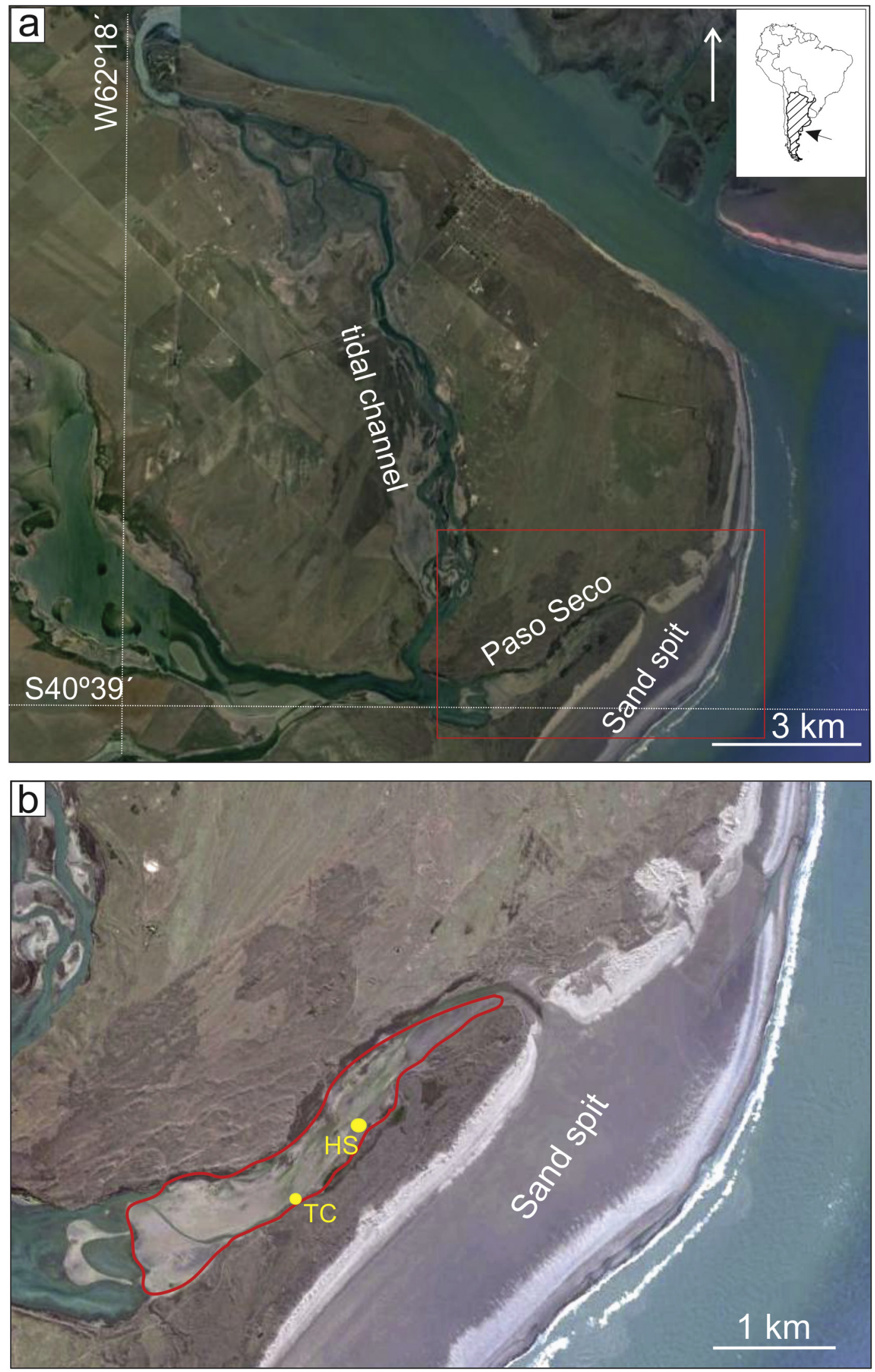

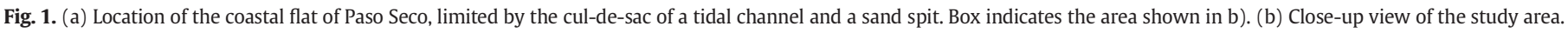

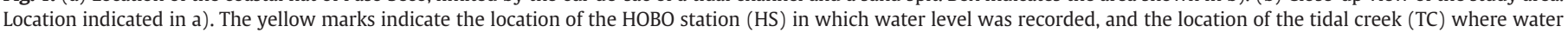
sample was taken. (For interpretation of the references to colour in this figure legend, the reader is referred to the web version of this article.) 
creek (TC) (Fig. 1b) and five samples from different ponds (P) with varying degrees of water evaporation. Water salinity was determined gravimetrically (Strickland and Parsons, 1972) and concentrations of $\mathrm{Ca}^{2+}$ and $\mathrm{CO}_{3}^{2-}$ from water were determined following standard methods (APHA, 2005); pH measured in water and sediment was carried out in the field with a HANNA HI991003 pH meter.

In order to analyse the sediments colonized by microbial mats, nine sedimentary cores (inner diameter $=4.5 \mathrm{~cm}$; depth $=22 \mathrm{~cm}$ ) were taken from the flat, which were subsequently studied under a SMZ Nikon 1500 stereoscopic zoom microscope. In addition, 33 thin sections were prepared for petrographic analysis. To prepare these thin sections, samples were left drying at room temperature $\left(\approx 20^{\circ} \mathrm{C}\right)$ for several days, and they were subsequently impregnated with a $4: 1$ ratio mixture of epoxy resin Dicast 867 and Discure 383 hardener. No chemical preservatives or fixatives were used in order to preserve the fluorescent pigments of the microbes. Thin sections were normally thicker than $30 \mu \mathrm{m}$ (traditional thickness of petrographic thin sections) to avoid losing fragments of sample. Several selected thin sections were stained with a solution of Potassium Ferrocyanide Ke (CN) 6, Alizarin and Hydrochloric Acid for determining the nature of the carbonate (Dickson, 1966). Thin sections were petrographically analysed in a Nikon Eclipse POL 50i transmitted-light microscope. The work was carried out under plane-polarised light and cross-polarised light to identify mineral species. Moreover, incident epifluorescence light microscopy was performed by using a $100 \mathrm{~W}$ mercury lamp (halogen) combined with different filters that were coupled to an Eclipse 50i POL petrographic microscope. UV (334-365 nm), blue light (435-490 nm) and green light $(546 \mathrm{~nm})$ filters were used to identify fluorescent pigments, organic matter and minerals. X-ray diffraction analysis was performed using a Rigaku D-Max III-C diffractometer with $\mathrm{CuK} \alpha$ radiation and a graphite
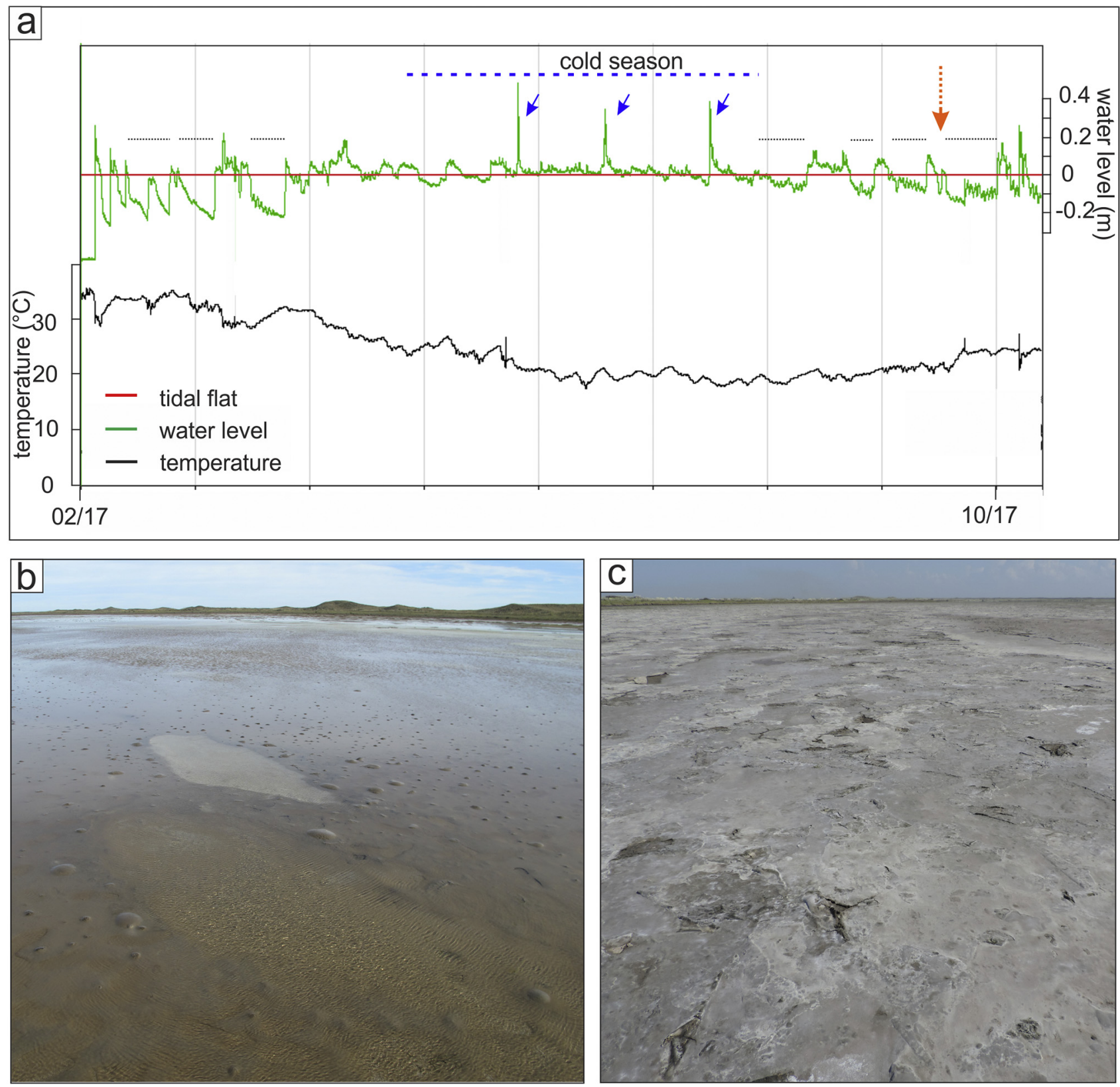

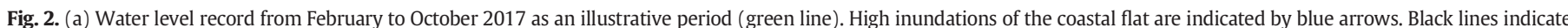

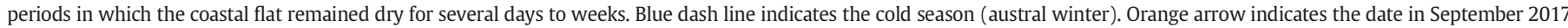

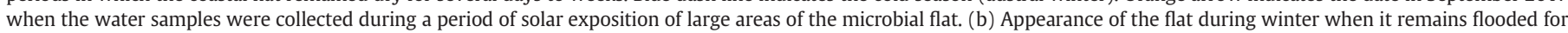

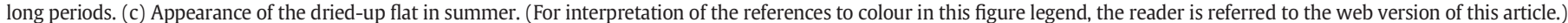


monochromator (Universidad Nacional del Sur, Argentina) to identify evaporitic minerals.

To observe the relationship between microorganisms, sediment, and EPS in depth, small blocks of sediment $\left(\approx 0.25 \mathrm{~cm}^{2}\right.$ in vertical section; $0.2 \mathrm{~cm}$ in width) were examined by using scanning electron microscopy (SEM). The sediment blocks were embedded with gluteraldehyde $2.5 \%$ immediately after field sampling to fix the organic matter. The SEM analyses were developed at CONICET Bahía Blanca (Argentina) using a LEO, EVO 40 XVP (2004) model at 20 $\mathrm{kV}$, and the elemental composition of the mats was studied by energy dispersion spectroscope (EDS) Oxford, X-Max 50 (2017) connected to the SEM. These SEM-EDS analyses were used to identify the morphology and distribution of mineral precipitates based on their chemical elements. Surface mapping techniques were used for the detection of chemical elements on the vertical section of sediment blocks. The linescan method was used to define the chemical element distribution along a line.

Table 1

pH values of water and sediment measured in 2017 and 2018. n/d: no data.

\begin{tabular}{lll}
\hline Date of measurement & Water $\mathrm{pH}$ & Sediment $\mathrm{pH}$ \\
\hline March 2017 & 9.1 & 9.89 \\
May 2017 & 7.14 & 8.25 \\
September 2017 & 8.29 & 8.33 \\
October 2017 & 7.87 & $\mathrm{n} / \mathrm{d}$ \\
March 2018 & $\mathrm{n} / \mathrm{d}$ & 7.03 \\
June 2018 & 8.49 & 8.63 \\
August 2018 & 8.14 & 8.61 \\
\hline
\end{tabular}

\section{Results}

\subsection{Water level fluctuations}

The coastal flat at Paso Seco is characterized by repeated water level fluctuations caused by recurrent seawater floods (Fig. 2a). During storms with strong winds, especially in coincidence with spring tides, Paso Seco flat is rapidly flooded by seawater, reaching water column heights of several tens of centimetres depending on the storm energy (20 to $70 \mathrm{~cm}$ ). After each flooding episode, the coastal flat remains under water $(\approx 10 \mathrm{~cm})$ for several days to weeks during the austral winter period (Fig. 2a, b). Conversely, during warm periods, progressive water evaporation may cause subaerial exposure of the flat (Fig. 2a, c).

\subsection{Hydrochemistry of Paso Seco}

Hydrochemistry analyses show $\mathrm{pH}$ values between neutral to alkaline (Table 1). On some occasions whiting waters were observed on the flat (Fig. 3a), presenting salinity values of around 115 and temperatures of $24.4{ }^{\circ} \mathrm{C}$. Salinity analysis of the water of the tidal creek (TC, Fig. 1b) and five shallow ponds in September 2017 (austral spring) showed an increment from the values in the TC to the different ponds due to increased degrees of evaporation in each pond (Fig. 3b). In addition, $\mathrm{Ca}^{2+}$ and $\mathrm{CO}_{3}^{2-}$ concentration values were closely related with salinity. Thus, as salinity increased, $\mathrm{CO}_{3}^{2-}$ concentration also increased, until salinity reached values of 99.35 (Fig. 3b). After that point, the carbonate ion was depleted, suggesting precipitation of carbonate minerals. Contrastingly, $\mathrm{Ca}^{2+}$ concentration increased until salinity
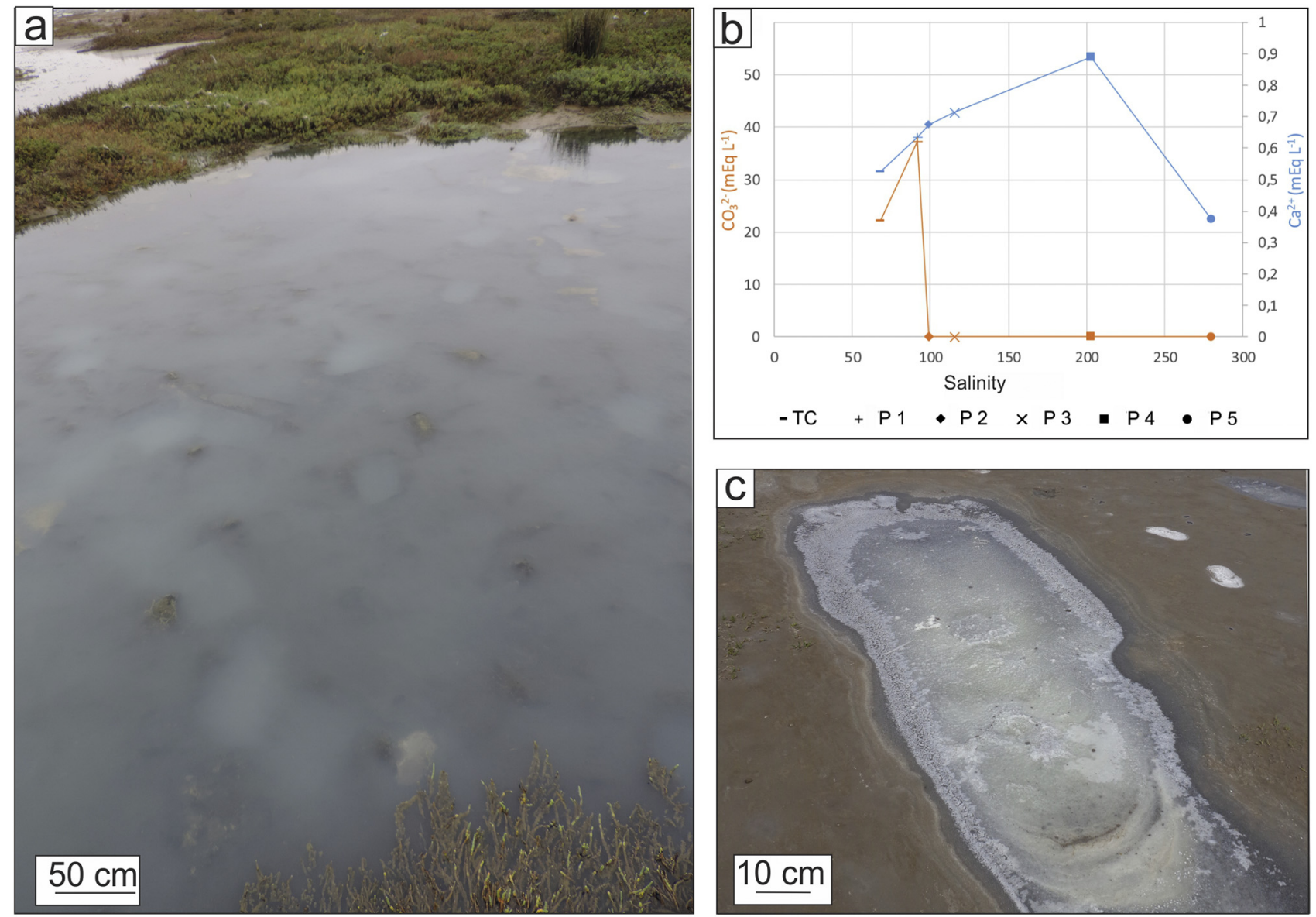

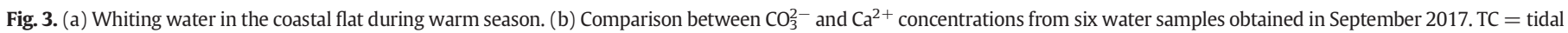
creek (see location in Fig. 1b), $\mathrm{Pn}=$ pond. (c) Evaporated pond with halite crystals during dry season. 
reached values of 202.51. Then, $\mathrm{Ca}^{2+}$ concentration in water abruptly dropped at a salinity of 279.4, when the precipitation of gypsum consumed the $\mathrm{Ca}^{2+}$ ions (Fig. 3b). Gypsum sheets (identified by X-ray analysis) were observed on the flat, and cubic halite crystals were present in the shallow pond that reached salinity values of 279.4 when the seawater is evaporated to $0.09-0.1$ of the original volume (as was seen by Usiglio, 1849) (Fig. 3c).

\subsection{Biogenic bedding}

Sedimentary cores from different locations of the tidal flat are characterized by the presence of biogenic bedding (sensu Gerdes and Klenke, 2007), consisting of vertical sequences of microbial mat layers in alternation with siliciclastic units (Fig. 4a). Microbial mats are laminated organomineral layers, $<1 \mathrm{~cm}$ in thickness. Thickness of siliciclastic layers varies from few millimetres to several centimetres and they are composed of medium to very fine-grained sand, consisting predominantly of quartz, plagioclase, potassium feldspar, amphibole, pyroxene, volcanic rock fragments, and minor magnetite grains. Bioclasts (ostracod, bivalve and foraminifera shells) are scarce. Few vertical burrows cut through both the sand layers and microbial mats.

Biogenic bedding is present all along the tidal flat. However, the thickness of the microbial mats and the siliciclastic units, as well as their proportions, varies in different sedimentary cores due to lateral and longitudinal changes in sediment transport. In addition, the development of different MISS (i.e., mat folds, roll-ups, flipped over edges, erosional pockets and others) along the tidal flat (Maisano et al., 2019) produces significant variations in the vertical sedimentary succession in the different cores.

\subsection{Microbial mat composition and microstructure}

\subsubsection{Petrographic study}

The petrographic study of the microbial mats allowed the identification of characteristic, laterally continuous, repetitive, up to $2 \mathrm{~mm}$-thick sequences composed of four different types of laminae (Fig. 4b-d), which are recognized both in the surficial living and in the buried microbial mats, developed in any location of the tidal flat. Each sequence begins with a sand to silt lamina (lamina A, Fig. 4c). Lamina A is overlain by a lamina of organic matter and clay to fine-grained silt (lamina B), which displays subvertical cyanobacteria filament moulds up to $20 \mu \mathrm{m}$ in diameter (fm in Fig. 4c, d) that continue into the overlying lamina, which is composed of dense micritic calcite (lamina C), whose mineralogy was identified by the staining method (Dickson, 1966). Finally, the uppermost lamina is composed of organic matter, showing a horizontal filamentous texture (lamina $\mathrm{D}$ ). The sequence may be successively repeated (Fig. 4d), and the main features of each of these laminae are described as follows.

Lamina $A$ is 0.15 to $1 \mathrm{~mm}$ in thickness and is composed of finegrained sand to silt (Fig. 5a, b), clearly seen in thin-section
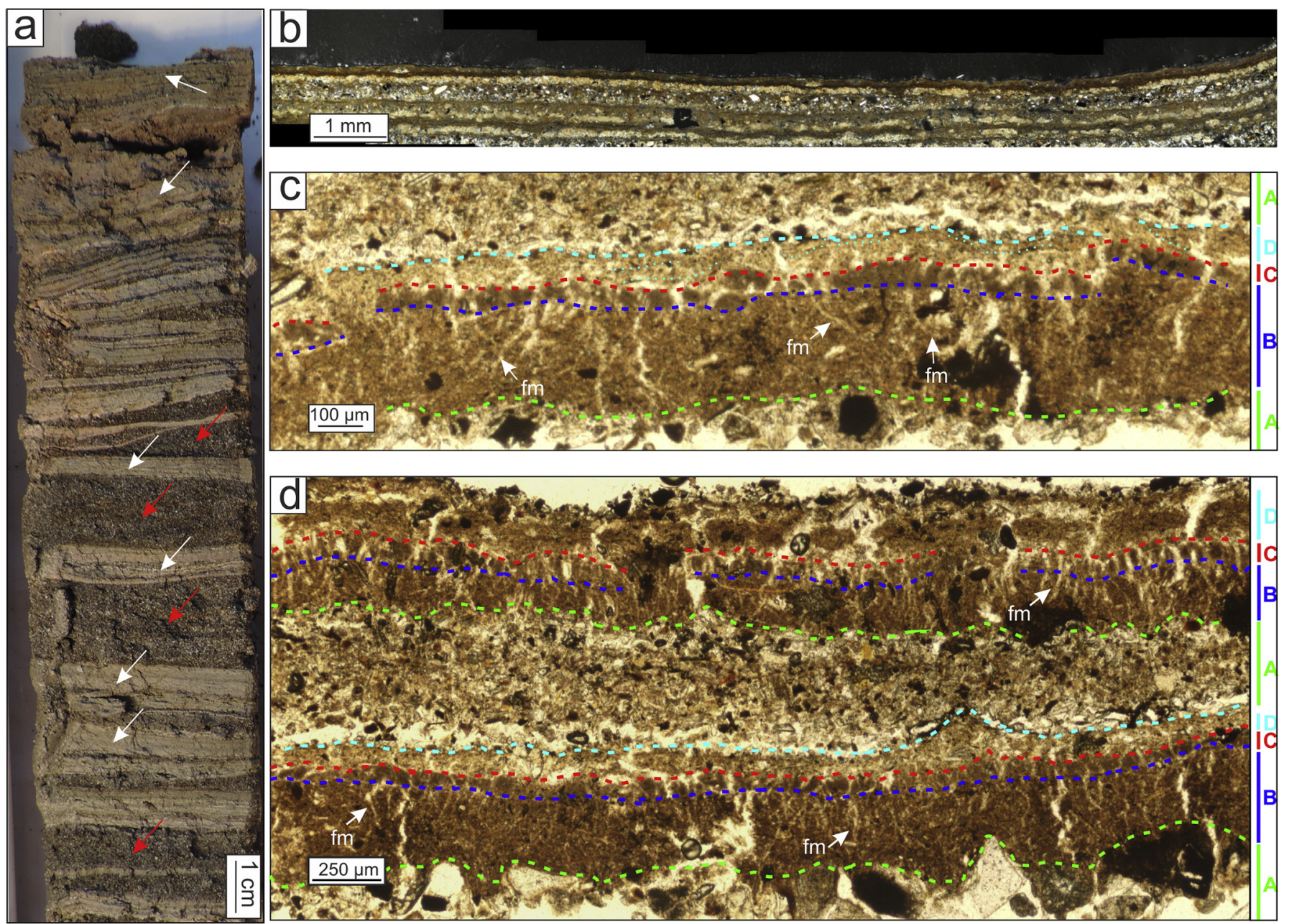

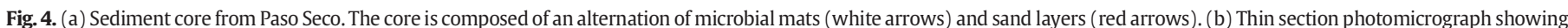

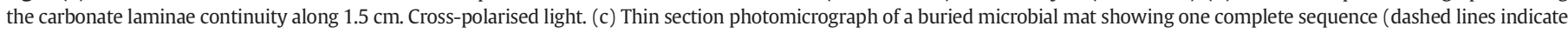

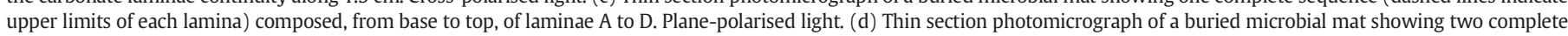
sequences. Plane-polarised light. (For interpretation of the references to colour in this figure legend, the reader is referred to the web version of this article.) 
photomicrographs with plane and cross-polarised light. The lower contact is sharp and commonly shows a fining-upwards trend. Lamina $B$ is finer than $A$, up to $400 \mu \mathrm{m}$ in thickness, and smoothly overlies lamina A (Fig. 5c, d). It is composed of detritic clay, fine silt and amorphous organic matter (probably EPS together with degraded cyanobacteria filaments), diatoms and cyanobacteria sheaths with different grades of preservation. This lamina is traversed by cyanobacteria filament bundles (in surficial mats) or their moulds (in buried microbial mats), which show elongated irregular shapes up to $20 \mu \mathrm{m}$ in diameter. The cyanobacteria bundles or moulds are predominantly subvertically-oriented continuing into the overlying lamina, as clearly seen in thin sections under plane-polarised light (yellow arrows in Fig. 5e).
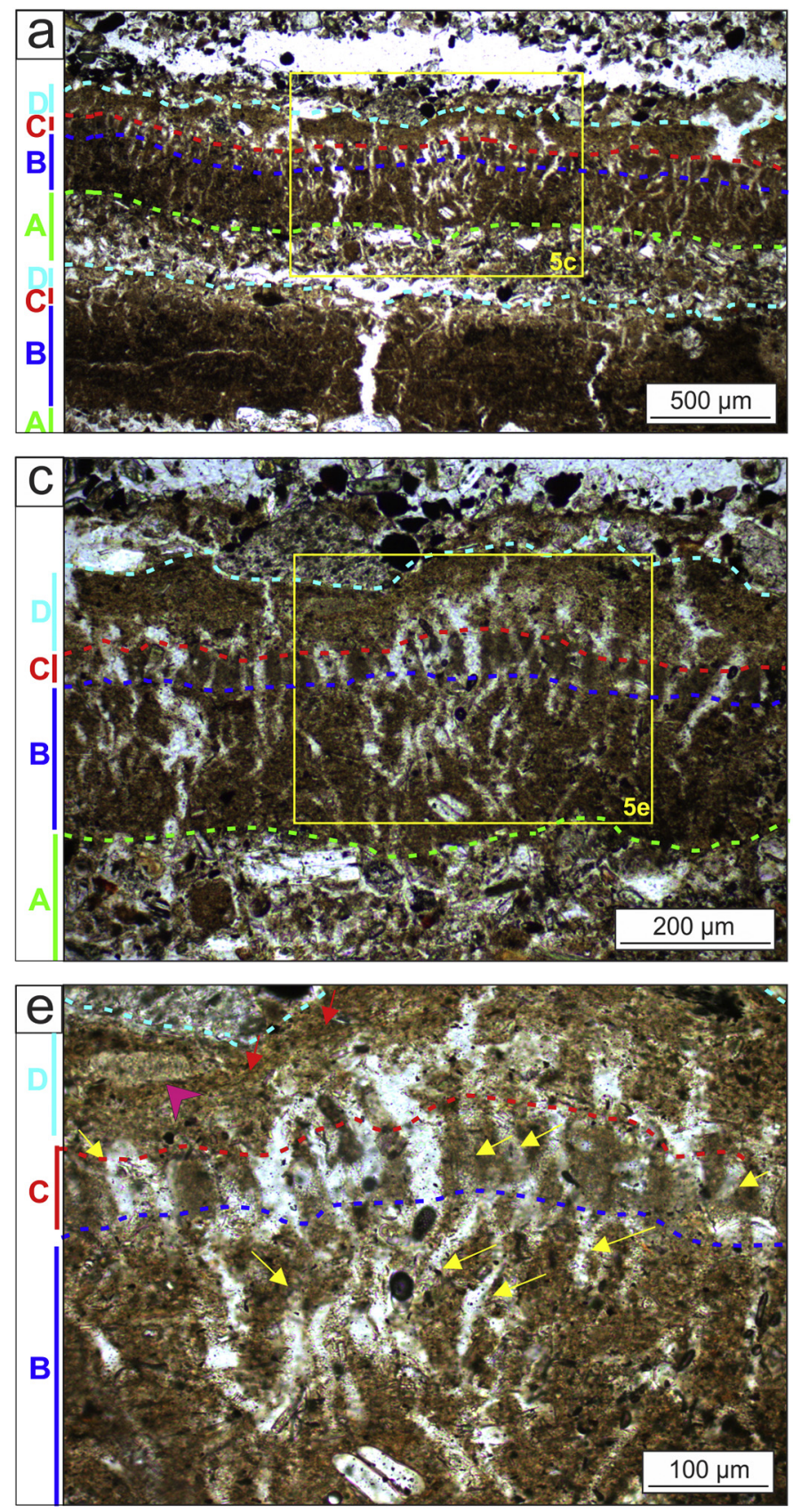

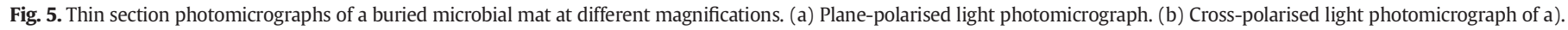

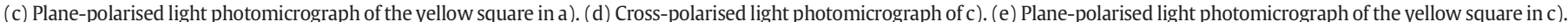

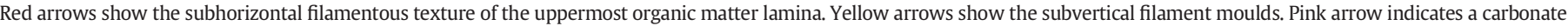

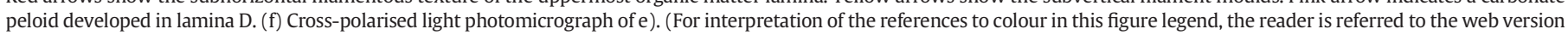
of this article.)
Lamina $C$ is up to $100-200 \mu \mathrm{m}$ in thickness and is composed of dense micritic calcite (Fig. 5e, f). The micritic lamina is also cut by subvertically-oriented cyanobacteria filaments or moulds. This lamina can be easily distinguished by the high-order interference colours of calcite under cross-polarised light (Fig. 5f).

Lamina D is up to $250 \mu \mathrm{m}$ in thickness and is composed of amorphous organic matter, diatoms and cyanobacteria sheaths with different grades of preservation (Fig. 5e, f). This lamina shows a predominantly subhorizontal, filamentous texture produced by the arrangement of cyanobacteria filaments sub-parallel to the sediment surface (red arrows in Fig. 5e and light blue lines in Fig. 6a). In addition, some areas of lamina D present disperse organic matter clumps that produce slight irregularities on the surface of this lamina (yellow arrows in Fig. 6b, c).
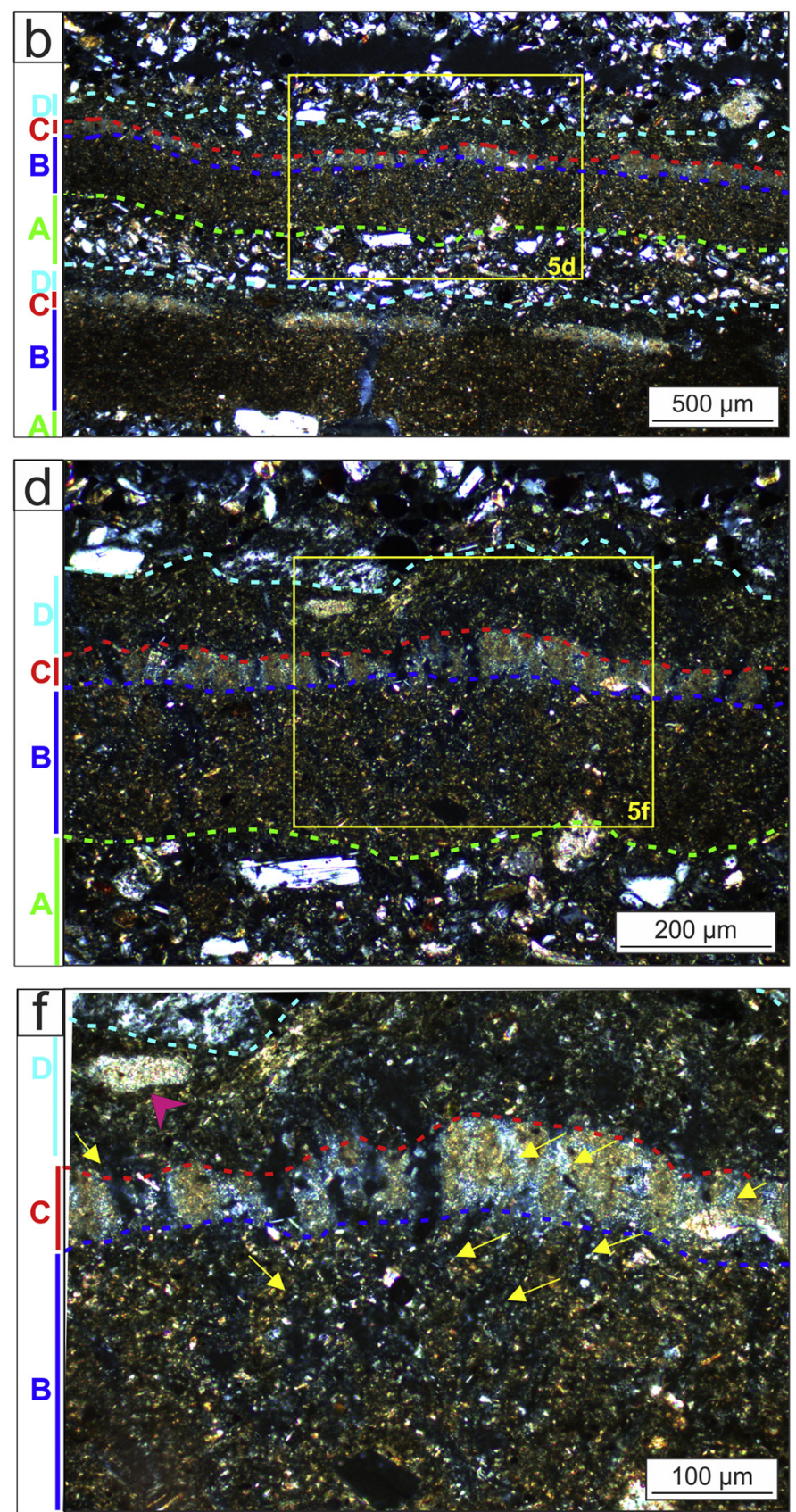

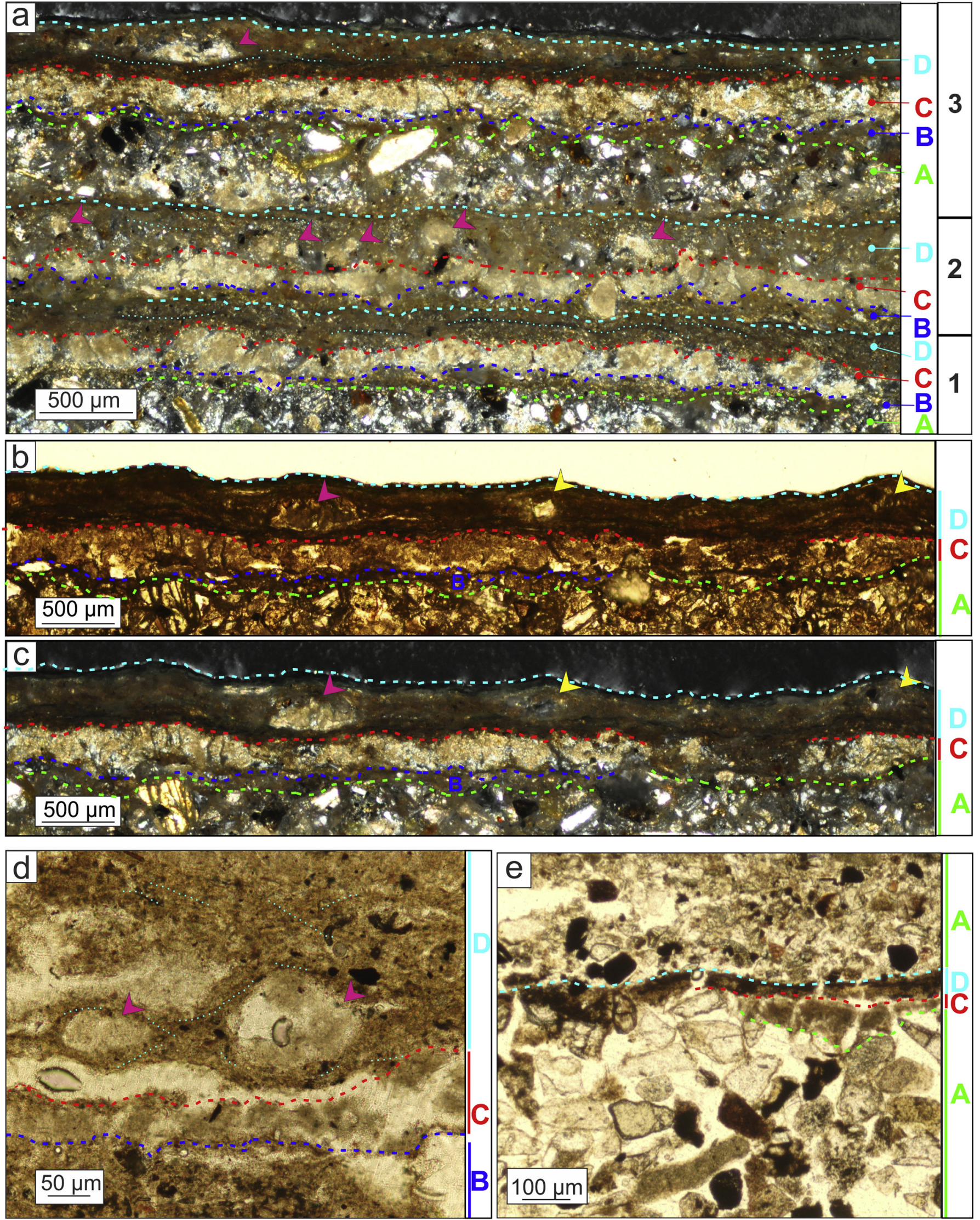

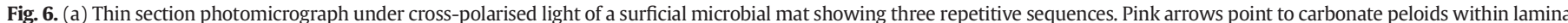

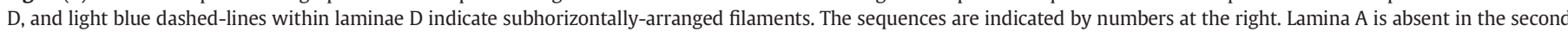

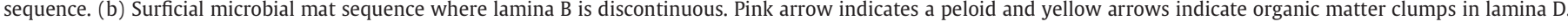

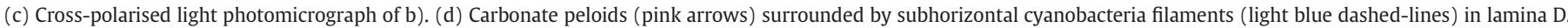

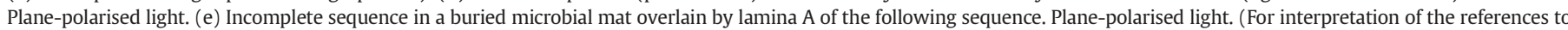
colour in this figure legend, the reader is referred to the web version of this article.) 
Some of these clumps are calcitized, resulting in carbonate peloids from 30 to $500 \mu \mathrm{m}$ in size (pink arrow in Fig. 5e-f, Fig. 6a-c), enclosed among the cyanobacteria filaments (Fig. 6d).

Although most of the sequences within the microbial mats include the four characteristic laminae (A to D), some sequences are not complete, with one or several laminae absent. Such is the case when sequences are composed of a fine-grained sand to silt lamina $(A)$ at the base, overlain directly by the micritic calcite lamina (or even the micrite may be among the sand grains in the upper part of lamina A) and, finally, covered by the organic-rich lamina D (Fig. 6b, c, e). Another case is when sequences do not show a lamina $A$ at the base, and consist only of organic-rich laminae (B and D) with a micritic lamina (C) between them (second sequence in Fig. 6a).

Analyses of the surficial mats under a stereoscopic zoom microscope (Fig. 7) discriminate the carbonate lamina (whitish colour), the laminae composed predominantly of amorphous organic matter (brownish colour), and the sand and silt layer (Fig. 7a, b). Moreover, cyanobacteria filaments (green colour) are clearly recognized under the stereoscopic zoom microscope, as well as diatoms on a topmost biofilm (Fig. 7a, b). Buried microbial mats several centimetres below the sediment surface show the same carbonate, organic matter, and sand and silt laminae, although in these buried microbial mats cyanobacteria filaments are not generally preserved, but vertical filamentous moulds occur instead (Fig. 7c).

\subsubsection{Epifluorescence analysis}

Different filters used in epifuorescence analysis allow the observation of the relationships between the cyanobacteria filaments and the mineral components, especially in samples of surficial microbial mats, in which the pigment contents of filament sheaths are better preserved.
The cyanobacteria filament sheaths, identified by blue light excitation filter present vertical and subvertical orientation among the sand and silt grains of lamina A (Fig. 8a, b). Calcitic lamina C, which shows greenish-yellowish colour with blue light excitation filter and red colour with green light filter, is also traversed by vertical to subvertical cyanobacteria sheaths (Fig. 8a, b) or their moulds in buried microbial mats (Fig. 8c, d). Lamina D shows bright yellow colour, under the blue light excitation filter, and also a horizontal to subhorizontal filamentous texture (which bends around the carbonate peloids) is identified (Fig. 8a, b). This bright yellow filamentous texture probably corresponds to cyanobacteria filament sheaths and diatom biofilm.

\subsubsection{SEM-EDS analysis}

Element mapping and linescan through blocks of microbial mats by SEM-EDS show repetitive continuous laminae (tens of micrometres thick) with a high content of $\mathrm{Ca}, \mathrm{C}$ and $\mathrm{O}$ (Fig. 9). This analysis corroborates the presence of calcite laminae observed under the petrographic microscope. A close-up view of the carbonate laminae reveals that they consist of irregular clusters of subglobular to globular clots composed of submicrometric carbonate grains (Fig. 10a-c). Each $\mathrm{CaCO}_{3}$ grain is a $<1 \mu \mathrm{m}$-sized, anhedral to subhedral crystal, and some $<2 \mu \mathrm{m}$ sized platy crystals are also occasionally present (arrows in Fig. 10c).

Furthermore, SEM analysis permits a detailed view of the arrangement of the cyanobacteria filaments in the microbial mats. Empty sheaths of cyanobacteria filaments and/or their moulds cross the micrite laminae, and they are oriented mainly vertically or subvertically (Fig. 10a, d). The filament sheaths or moulds change to a horizontal or subhorizontal orientation at the overlying lamina D (yellow arrows in Fig. 10a). The walls of cyanobacteria moulds present a smoother appearance due to the presence of microbial EPS (Fig. 10d), and even some of
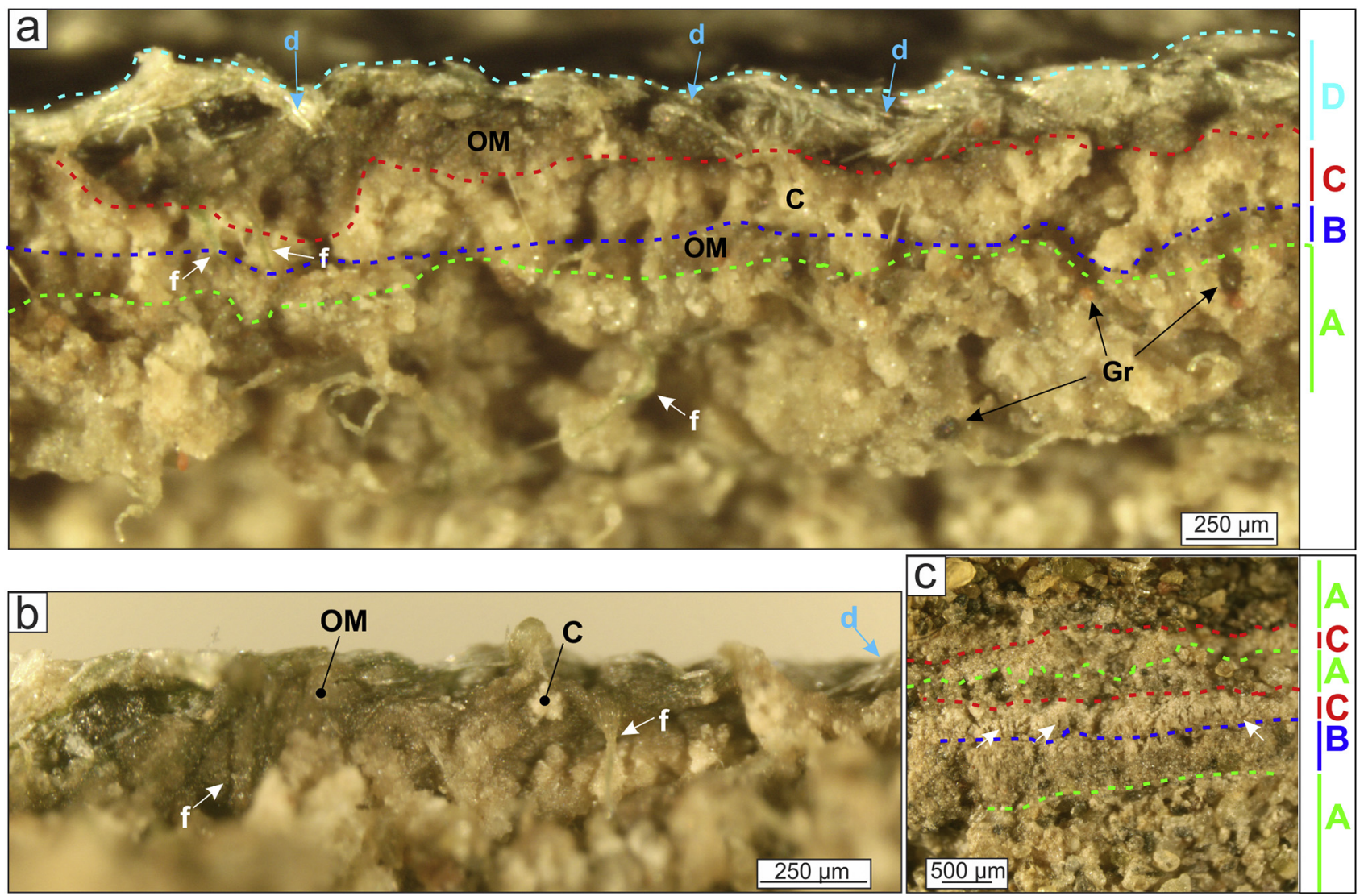

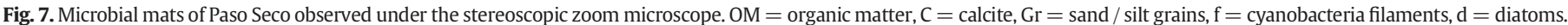

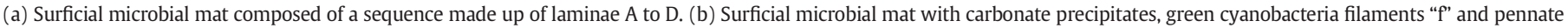

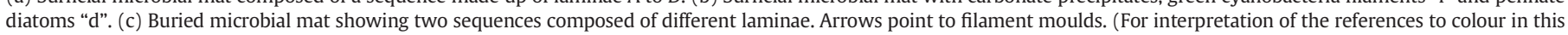
figure legend, the reader is referred to the web version of this article.) 

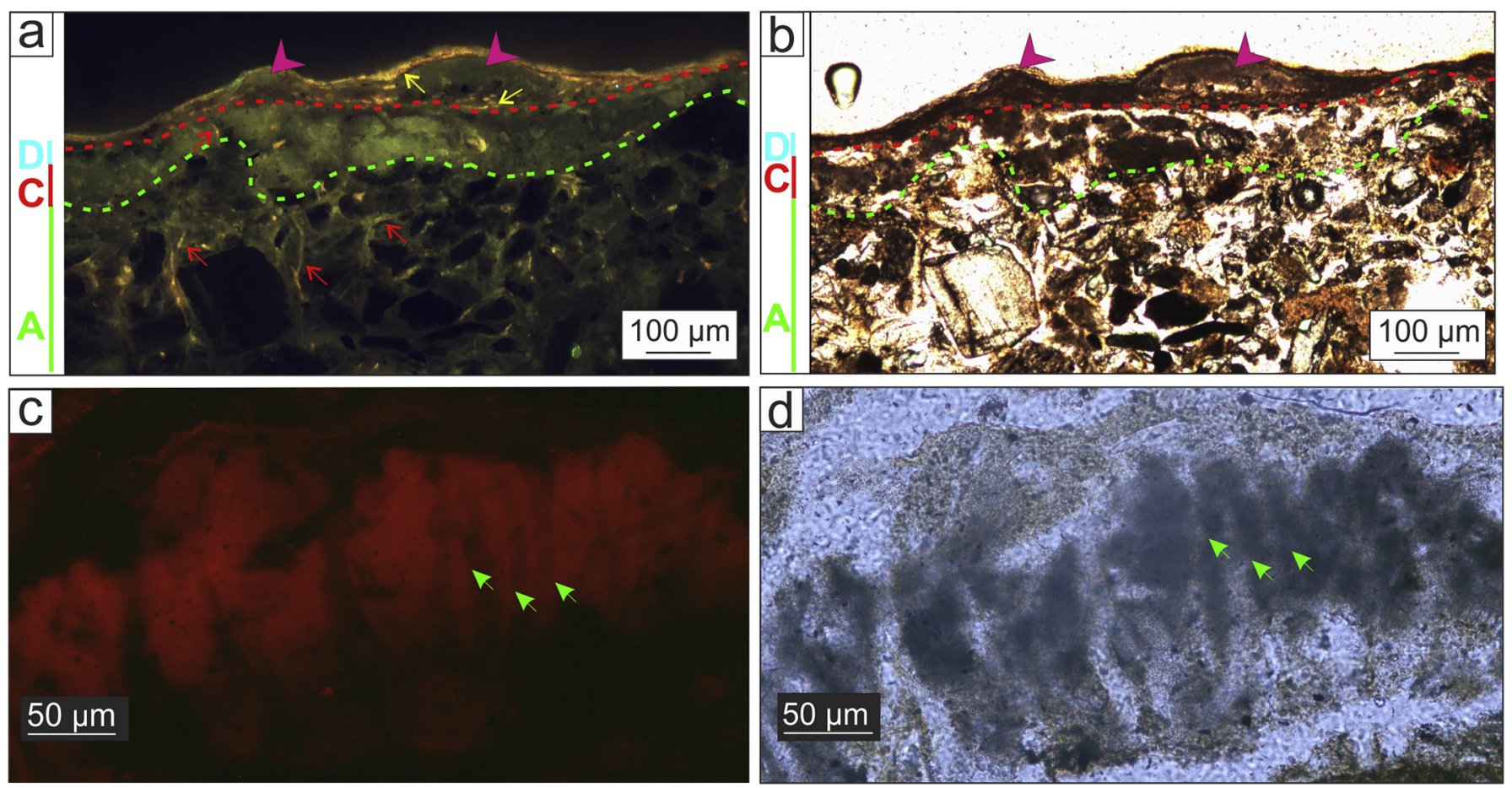

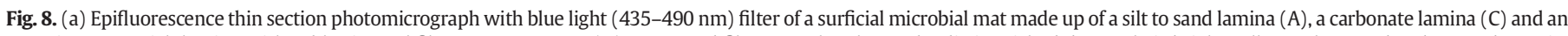

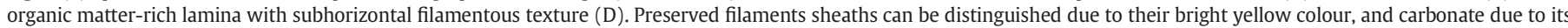

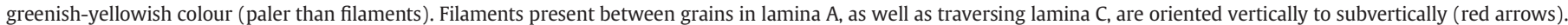

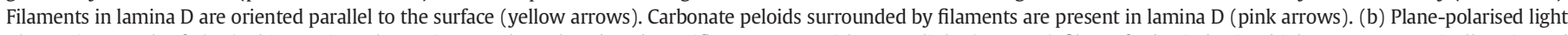

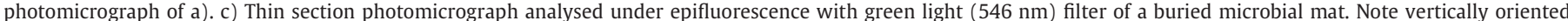

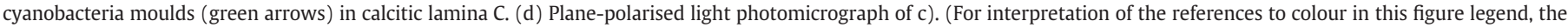
reader is referred to the web version of this article.)

the mucilaginous external sheaths of cyanobacteria are preserved (Fig. 10d, right).

\section{Interactions between biotic and abiotic factors that control car- bonate precipitation}

The flat microbial mats of Paso Seco provide an excellent case study to document the formation of distinctive, continuous, and repeated carbonate laminae in microbial mats from a predominantly siliciclastic supratidal flat developed in a progradational coastal system, which is strongly controlled by cyclic environmental changes that produce recurrent saline conditions. The hydrodynamic conditions in Paso Seco are characterized by a recurring (not periodic) pattern marked by flooding events during storm surges that produce a rapid increase in water depth over the flat (Fig. 2a). Ebb currents are slow because seawater is retained on the flat due to its semi-closed topography, which delays water retreat after the inflow event. Water retention is additionally favoured by the presence of epibenthic microbial mats, which causes a decrease in sediment permeability (a 5.1-times slower water infiltration rate than where no microbial mats are present; Perillo et al., 2019). The retained water progressively evaporates, especially when temperatures are warm and intense and frequent drying winds prevail.

During the process of evaporitic concentration, particular ions in the brine increase together with the increase in salinity. Thus, the seawater evaporation follows the first steps of the sequence of crystallization up to saturation of salts in agreement with solar saltwork, where carbonate precipitates at salinities between 70 and 140 (Babel and Schreiber, 2014). The initial $\mathrm{Ca}^{2+}$ concentration increase is due to reduced water volume by evaporation, but when the half of the initial volume of seawater is reached, $\mathrm{CaCO}_{3}$ begins to precipitate (Usiglio, 1849), which is sustained by the total depletion of $\mathrm{CO}_{3}^{2-}$ from the solution (Fig. 3b). This agrees with Ludwig et al. (2005) who supported that calcification does not depend only on the concentration of $\mathrm{Ca}^{2+}, \mathrm{pH}$ and alkalinity, but also on $\mathrm{CO}_{3}^{2-}$ concentration. Thus, carbonate precipitation is probably a purely chemical process, and the role that microbial metabolic activity plays in the process is not known. However, the presence of whiting hypersaturated waters during warm seasons (Fig. 3a) suggests that carbonate precipitation could be biologically-influenced (sensu Dupraz et al., 2009). Even though there are few studies on this subject, some authors sustain that whitings are related to microbial activity, being an outcome of photosynthesis (Thompson et al., 1994), or considered to be part of a mechanism directly associated with marine phytoplankton as diatoms (although it is not possible to confirm the formation process; Long et al., 2017), or related to autotrophic picoplankton in oligotrophic lakes (Dittrich and Obst, 2004). Riding (2000) argued that seawater becomes milky due to the suspension of microcrystalline calcite crystals, which can be associated with microbe blooms and floccules that can be sites of nucleation. Regarding these considerations, microbial cells or EPS suspended in the water column of the saline basin of Paso Seco might act as nucleation sites for carbonate precipitation when $\mathrm{CaCO}_{3}$ supersaturation is achieved due to seawater evaporation. Additionally, while water concentration above the mats is at $\mathrm{CaCO}_{3}$ supersaturation point, carbonate might also precipitate in the EPS of the microbial mats, forming the peloids in laminae D (Fig. 6a-c, pink arrows).

A conceptual interpretation of the sedimentary and microbial processes that could control the cyclic character of the sedimentation and lead to carbonate precipitation is sketched in Fig. 11a. During the frequent flooding events, sandy and silty sediments are transported and deposited onto the flat surface (stage I in Fig. 11a). The flooding event, thus, may generate the sandy to silty lamina $A$, which would constitute the basal layer of each sequence. The granulometry and thickness of this lamina depend on the energy of the event, so very thin laminae might be present, or even lamina A can be missing if the velocity of the flooding current is not high enough to transport grains (sequence 2 in Fig. 6a). 

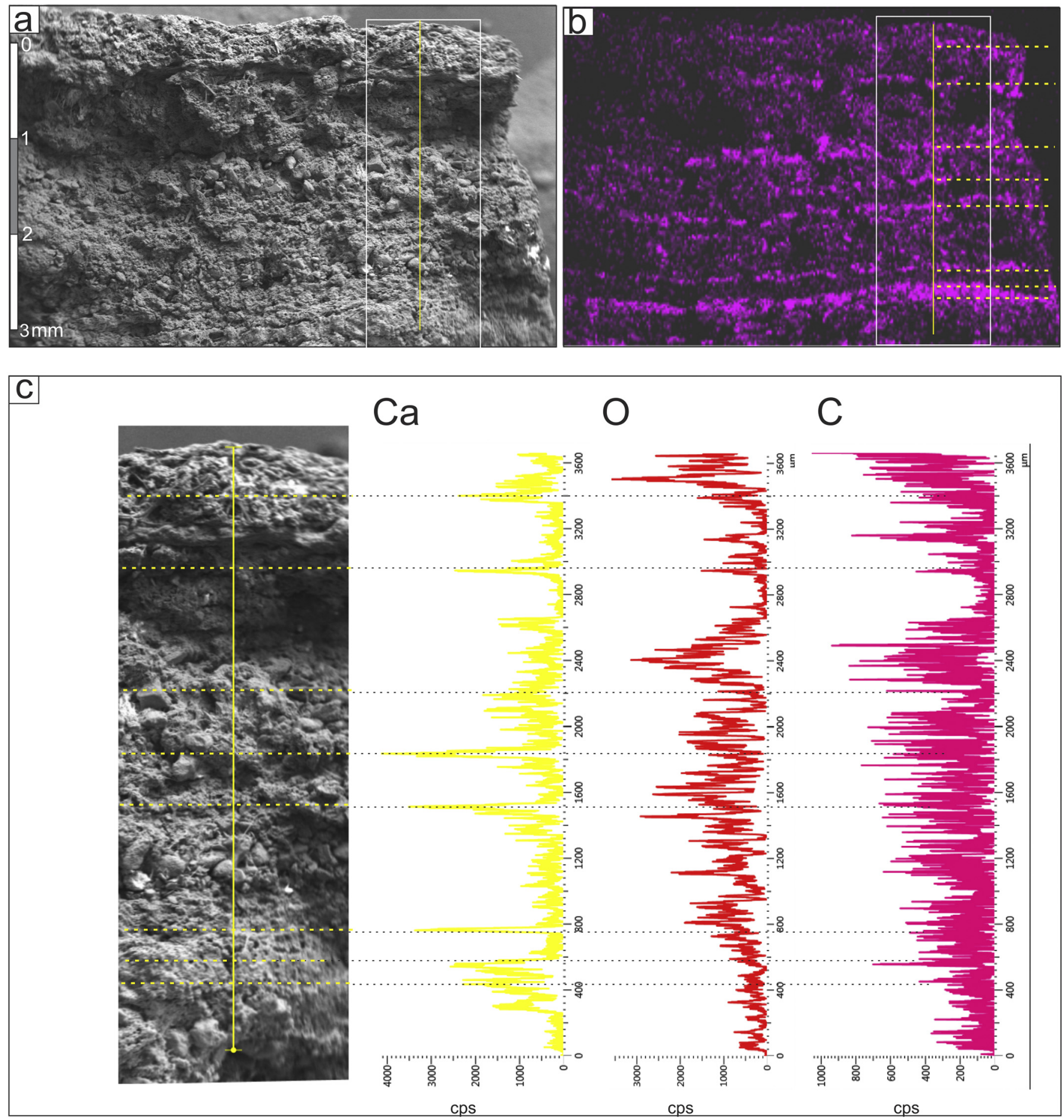

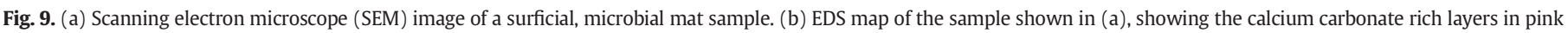

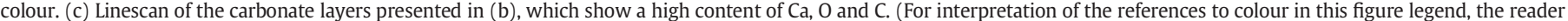
is referred to the web version of this article.)

After inundation, water level lowers gradually, and the flat remains covered with stagnant seawater $(\approx 10 \mathrm{~cm})$, sometimes for several days to weeks during the cold season (Fig. 2a). During this time, calm conditions prevail, and organic matter is produced by photosynthetic microbial activity (stage II in Fig. 11a). The filamentous cyanobacteria present within the microbial mat migrate vertically to the sediment surface to reach the supernatant water and towards more intense light conditions (Consalvey et al., 2004; Cuadrado, 2020). This vertical migration is evidenced by the vertical and subvertical orientation of the cyanobacterial filament bundles (or their moulds) in lamina A and lamina B (Figs. 4c, d, 5, 8). The linear dimensions of these filaments and moulds found in thin-section petrographic slides are consistent with the diameters of dominant oscillatorian cyanobacteria present in the area (see Table 2 in Cuadrado and Pan, 2018). The verticallyoriented filaments on the microbial mat surface may also increase the dynamic viscosity of the water and enhance the fall-out of silt and clay particles (baffling and trapping; Noffke, 2010). As a result, lamina B composed of organic matter, silt, and clay, and displaying verticallyoriented cyanobacteria trichomes or moulds, develops (Figs. 4c, d, 5). However, on some occasions, especially during summer, the flat might 

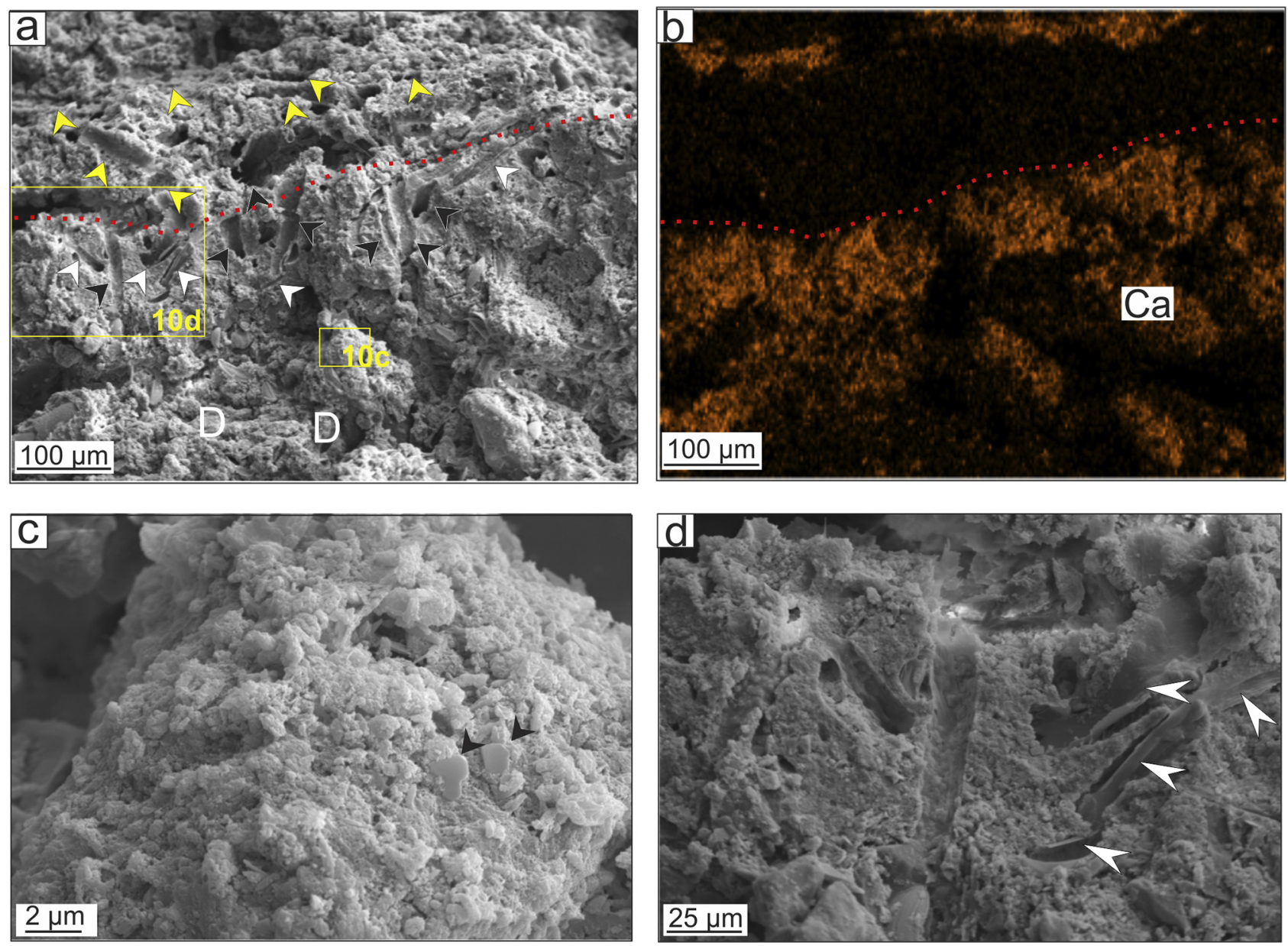

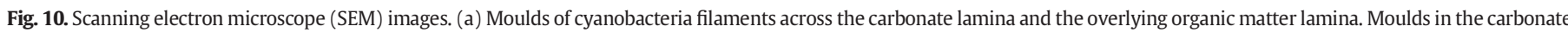

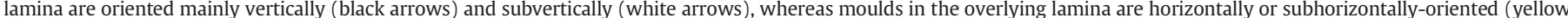

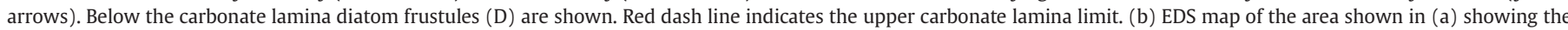

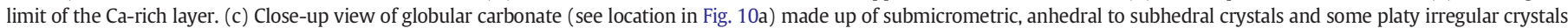

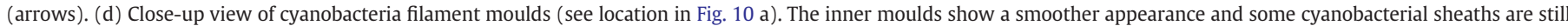
encased in the moulds (arrows in the right). (For interpretation of the references to colour in this figure legend, the reader is referred to the web version of this article.)

remain covered by seawater for a brief period of time and not long enough to develop lamina B (Fig. 6b, c), because of quick water evaporation caused by higher temperatures than in winter or/and windy conditions.

The seawater retained in the basin is subject to evaporation, and consequently the salinity of the remaining water gradually increases up to the $\mathrm{CaCO}_{3}$ supersaturation point, which normally triggers carbonate precipitation (see Kaźmierczak et al., 2015). At this point, whiting might occur where suspended cells (diatoms), cyanobacteria sheaths, or EPS molecules act as nucleation sites for microcrystalline calcite crystals, which will finally deposit, covering the sedimentary surface (stage III in Fig. 11a). Cyanobacteria filaments in microbial mat continue their upward movement, leaving moulds in micritic calcite in lamina $C$ (Figs. 5e, f, 8c, d, 10a, d); furthermore, some of the mucilaginous external sheaths of cyanobacteria, which are inhibited in degradation due to their fibrillary nature, are preserved (Li and Devaux, 2001) (detail in Fig. 10d, right). The morphology of mat-forming microbiota preservation is due to intense and fast carbonate precipitation that impedes the bacteriolysis decay of the original cell configuration (see Kaźmierczak et al., 2015).

Following carbonate precipitation, when the flat becomes almost completely dried, the microorganisms adopt a horizontal orientation, parallel to the surface (stage IV in Fig. 11a), and lamina D composed of amorphous organic matter, diatoms and cyanobacteria sheaths, is developed (Figs. 5e, f, 6, 7a, b, 8a, b). Similar alternating orientation of cyanobacterial filaments was documented by Monty (1967) in carbonate tidal flats from Andros Island (Bahamas). Likewise, this feature was also interpreted as the result of alternating periods with sufficient moisture for microbial mat formation, favouring vertical growth of cyanobacteria, and periods of drought during which the cyanobacteria filaments flatten.

Carbonate peloids present in some laminae D (Figs. 5e, f, 6a-d, 8a, b) resemble the peloids enclosed by cyanobacteria filaments described by Gerdes et al. (1994) in microbial mats from a salina in Lanzarote (Canary Islands, Spain). The subrounded to elongated morphology of the carbonate peloids and their surrounding elastic biogenic tissue (Fig. 6b-d) suggest that peloid formation is strongly influenced by the microorganisms of the mat community and their arrangement in lamina D. Furthermore, there is a close similarity in shape, size, and location of the carbonate peloids with the proximate organic matter clumps that occur also in lamina D (Fig. 6b, c). These clumps were previously studied in Paso Seco by Cuadrado and Pan (2018), who demonstrated that the motility of filamentous cyanobacteria produces areas of higher density of cyanobacterial trichomes. Sim et al. (2012) stated that clumps (denser cyanobacterial filaments and heterotrophic microbes) promote the retention of carbon and the assimilation of inorganic carbon, and therefore, it is possible that they serve as calcite nucleation sites likely related to mat decay (see Gerdes, 2007). Moreover, based on laboratory experiments, Riege et al. (1991) suspected that aerobic degradation of the organic acids produced by cyanobacteria and other microorganisms 


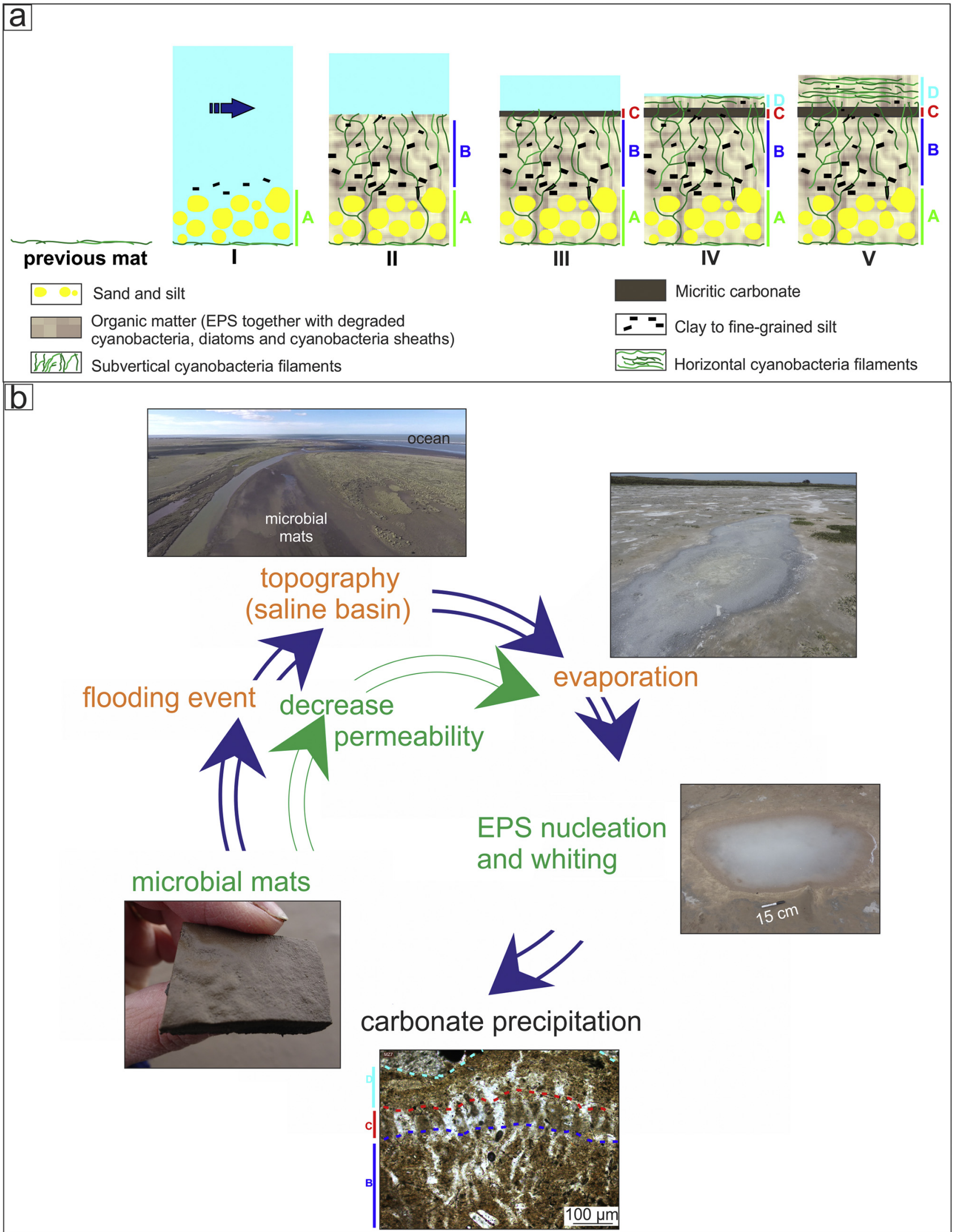

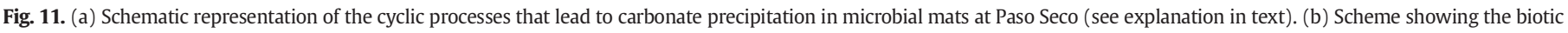

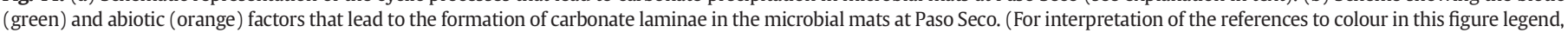
the reader is referred to the web version of this article.) 
could lead to carbonate precipitation. In a similar way, Arp et al. (2012) and Ionescu et al. (2015) claimed that carbonate precipitation in microbial mats of a hypersaline lake on the atoll of Kiritimati was related to aerobic heterotrophic decomposition of $\mathrm{Ca}^{2+}$ binding EPS, which released $\mathrm{Ca}^{2+}$ and decreased kinetic inhibition for carbonate precipitation caused by EPS. Therefore, regarding all these considerations, carbonate peloids observed in lamina D of the microbial mats of Paso Seco are interpreted as the result of carbonate precipitation on decaying organic matter clumps.

At the end of the sequence, progressive water evaporation on the flat produces precipitation of gypsum and halite, as was revealed by field observations and corroborated by X-ray analysis (Fig. 3c). However, these minerals are not preserved in the sedimentary sequence because they are dissolved during the following inundation. Eventually, water evaporation, coupled with slow water infiltration, may lead to subaerial exposure of the mat surface (stage V in Figs. 2a, c, 11a).

The good correlation between the characteristic sedimentary sequences recorded in the microbial mats and the recurrent environmental changes that take place in Paso Seco indicates that sedimentation is strongly controlled by environmental factors. Thus, the formation of carbonate laminae within these low-relief microbial mats of a siliciclastic environment is due to the interplay of abiotic and biotic factors (Fig. 11b). The development of suitable conditions for carbonate precipitation in this environment suggests that similar processes may occur in other siliciclastic settings colonized by microbial mats and in which saline conditions are recurrently developed, which, by analogy with the present case study, may occur in progradational coastal settings. A more intense effort on the study of microbial mats of such sedimentary environments may contribute to build bridges between the carbonate and siliciclastic research areas into which the study of microbial mats has been traditionally divided.

\section{Conclusions}

This contribution documents well-defined, cyclic and laterallycontinuous carbonate laminae in low-relief microbial mats from a modern, siliciclastic, supratidal flat. Both physical and biotic factors most likely play a strong role in sedimentation and carbonate precipitation in the microbial mats studied.

The most important abiotic factors are the temperate semiarid climate and the topography of the tidal flat environment, which together produce a semi-closed saline basin, where the seawater, recurrently recharged, becomes stagnant and covers the flat for several days to weeks. Then, the $\mathrm{CaCO}_{3}$ supersaturation conditions necessary for carbonate precipitation are attained due to evaporation. The presence of a continuous microbial mat over large areas of the sedimentary basin constitutes a significant biotic factor, as it increases the impermeability of the sediment surface, making gradual evaporation possible. Furthermore, microbial mats may also play a key role in the formation of the carbonate laminae by providing a nucleus for precipitation, both as sheath-encased microbial cells or EPS within the water column, which will eventually settle down on the microbial mats, and as organic matter in the microbial mats, which may later calcify in situ.

\section{Declaration of competing interest}

The authors declare that they have no known competing financial interests or personal relationships that could have appeared to influence the work reported in this paper.

\section{Acknowledgements}

This work was supported by funding from Argentinian CONICET (PIP $2013 \mathrm{~N}^{\circ} 4061$ ) and SECYT-UNS (PGI 24/H138), the Spanish MINECO projects (CGL2014-52670-P and PGC2018-094034-B-C21), and José Castillejo program (CAS16/00124 and CAS17/00270). The authors are grateful to the editor J. Knight and two anonymous reviewers for their careful and thoughtful reviews. We would like to thank the staff of the UNS/INGEOSUR Petrotomy Laboratory, N. Cesaretti who helped in luminiscence works, C. Gutierrez Ayesta from the Microscopy Laboratory CCTBB, and the Stratigraphy Laboratory of the Complutense University of Madrid for their technical support. We are also very grateful to Eduardo A. Gomez and Luis Ariel Raniolo for their help during fieldwork, and to M. Isabel Benito for her helpful and enriching discussion.

\section{References}

Achal, V., Mukherjee, A., Reddy, M.S., 2010. Biocalcification by Sporosarcina pasteurii using corn steep liquor as nutrient source. Ind. Biotechnol. 6, 170-174.

Aliaga, V.S., Ferrelli, F., Piccolo, M.C., 2017. Regionalization of climate over the Argentine Pampas. Int. J. Climatol. 37, 1237-1247.

Altermann, W., Kazmierczak, J., Oren, A., Wright, D.T., 2006. Cyanobacterial calcification and its rock-building potential during 3.5 billion years of Earth history. Geobiology 4, 147-166.

APHA, 2005. Standard Methods for the Examination of Water and Waste Water. 21st ed American Public Health Association, Washington, DC.

Arp, G., Reimer, A., Reitner, J., 2001. Photosynthesis-induced biofilm calcification and calcium concentrations in Phanerozoic oceans. Science 292, 1701-1704.

Arp, G., Reimer, A., Reitner, J., 2003. Microbialite formation in seawater of increased alkalinity, Satonda Crater Lake, Indonesia. J. Sediment. Res. 73, 105-127.

Arp, G., Helms, G., Karlinska, K., Schumann, G., Reimer, A., Reitner, J., Trinchet, T., 2012. Photosynthesis versus exopolymer degradation in the formation of microbialites oh the Atoll of Karitimati, Republic of Kiribati, Central Pacific. Geomicrobiol J. 29, 29-65.

Babel, M., Schreiber, B.C., 2014. Geochemistry of evaporites and evolution of seawater. In: Holland, H.D., Turekian, K.K. (Eds.), Treatise on Geochemistry. Elsevier, Amsterdam, pp. 483-560.

Benzerara, K., Menguy, N., López-García, P., Yoon, T.H., Kazmierczak, J., Tyliszczak, T. Guyot, F., Brown Jr., E., 2006. Nanoscale detection of organic signatures in carbonate microbialites. Proc. Natl. Acad. Sci. U.S.A. 103, 9440-9445.

Berner, R.A., 1985. Sulphate reduction, organic matter decomposition and pyrite formation. Philos. Trans. R. Soc. A Math. Phys. Eng. Sci. 315, 25-38.

Bhaskar, P.V., Bhosle, N.B., 2005. Microbial extracellular polymeric substances in marine biogeochemical processes. Curr. Sci. 88, 45-53.

Bontognali, T.R., Vasconcelos, C., Warthmann, R.J., Bernasconi, S.M., Dupraz, C. Strohmenger, C.J., McKenzie, J.A., 2010. Dolomite formation within microbial mats in the coastal sabkha of Abu Dhabi (United Arab Emirates). Sedimentology 57, 824-844.

Burne, R.V., Moore, L.S., 1987. Microbialites: Organosedimentary deposits of benthic microbial communities. Palaios 2, 241-254.

Chafetz, H.S., Buczynski, C., 1992. Bacterially induced lithification of microbial mats. Palaios 7, 277-293.

Consalvey, M., Paterson, D.M., Underwood, G.J., 2004. The ups and downs of life in a benthic biofilm: migration of benthic diatoms. Diatom Res. 19, 181-202.

Cuadrado, D.G., 2020. Geobiological model of ripple genesis and preservation in heterolithic sedimentary sequence for a supratidal area. Sedimentology https://doi. org/10.1111/sed.12718.

Cuadrado, D.G., Pan, J., 2018. Field observations on the evolution of reticulate patterns in microbial mats in a modern siliciclastic coastal environment. J. Sediment. Res. 88, 24-37.

Défarge, C., Trichet, J., Coute, A., 1994. On the appearance of cyanobacterial calcification in modern stromatolites. Sediment. Geol. 94, 11-19.

Défarge, C., Trichet, J., Jaunet, A.-M., Robert, M., Tribble, J., Sansone, F.J., 1996. Texture of microbial sediments revealed by cryo-scanning electron microscopy. J. Sediment. Res. 66, 935-947.

Demicco, R.V., Hardie, L.A., 1994. Sedimentary structures and early diagenetic features of shallow marine carbonate deposits. Society for Sedimentary Geology, Atlas Series. 1 265 pp.

Dickson, J.A.D., 1966. Carbonate identification and genesis as revealed by staining J. Sediment. Petrol. 36, 491-505.

Dittrich, M., Obst, M., 2004. Are picoplankton responsible for calcite precipitation in lakes? AMBIO 33, 559-565.

Douglas, S., Beveridge, T.J., 1998. Mineral formation by bacteria in natural microbial communities. FEMS Microbiol. 26, 79-88.

Dupraz, C., Vissher, P., 2005. Microbial lithification in marine stromatolites and hypersaline mats. Trends Microbiol. 13, 429-438.

Dupraz, C., Reid, R., Braissan, O., Decho, A., Norman, R., Visscher, P., 2009. Processes of carbonate precipitation in modern microbial mats. Earth Sci. Rev. 96, 141-162.

Espinosa, M.A., Isla, F.I., 2011. Diatom and sedimentary record during the mid Holocene evolution of the San Blas estuarine complex, northern Patagonia, Argentina. Ameghiniana 48, 411-423.

Ferrelli, F., Bohn, V.Y., Piccolo, M.C., 2012. Variabilidad de la precipitación y ocurrencia de eventos secos en el sur de la provincia de Buenos Aires (Argentina). IX Jornadas Nacionales de Geografía Física, Abstract book. pp. 15-28.

Garrett, P., 1970. Phanerozoic stromatolites: noncompetitive ecologic restriction by grazing and burrowing animals. Science 169, 171-173. 
Gerdes, G., 2007. Structures left by modern microbial mats in their host sediments. In: Schieber, J., Bose, P.K., Eriksson, P.G., Banerjee, S., Sarkar, S., Altermann, W. Catuneanu, O. (Eds.), Atlas of Microbial Mat Features Preserved Within the Siliciclastic Rock Record. Elsevier, Amsterdam, pp. 5-38.

Gerdes, G., Klenke, T., 2007. States of biogenic bedding as records of the interplay of ecologic time and environment (a case study of modern siliciclastic sediments, Mellum Island, southern North Sea). Senckenberg. Marit. 37, 129-144.

Gerdes, G., Dunajtschik-Piewak, K., Riege, H., Taher, A.G., Krumbein, W.E., Reineck, H.E 1994. Structural diversity of biogenic carbonate particles in microbial mats. Sedimentology 41, 1273-1294.

Hardie, L.A., Ginsburg, R.N., 1977. Layering: The origin and environmental significance of lamination and thin bedding. In: Hardie, L.A. (Ed.), Sedimentation on the Modern Carbonate Tidal Flats of Northwest Andros Island. Bahamas. Studies in Geology. The Johns Hopkins University Press, Baltimore, pp. 50-123.

Ionescu, D. Spitzer, S., Reimer, A Schneider, D., Daniel, R., Reitner, J., De Beer, D., Arp, G 2015. Calcium dynamics in microbialite-forming exopolymer-rich mats on the atoll of Kiritimati, Republic of Kiribati, Central Pacific. Geobiology 13, 170-180.

Kaźmierczak, J., Kempe, S., Altermann, W., 2004. Microbial origin of Precambrian carbonates: lessons from modern analogues. In: Eriksson, P.G., Altermann, W., Nelson, D.R. Mueller, W.U., Catuneanu, O. (Eds.), the Precambrian Earth: Tempos and Events. Elsevier, Amsterdam, pp. 545-564.

Kaźmierczak, J., Fenchel, T., Kühl, M., Kempe, S., Kremer, B., Łącka, B., Małkowski, K, 2015. $\mathrm{CaCO}_{3}$ precipitation in multilayered cyanobacterial mats: clues to explain the alternation of micrite and sparite layers in calcareous stromatolites. Life 5 , 744-769.

Kinsman, D.J.J., Park, R.K., 1976. Algal belt and coastal sabkha evolution, Trucial Coast, Persian Gulf. In: Walter, M.R. (Ed.), Stromatolites. Developments in Sedimentology 20. Elsevier, Amsterdam, pp. 421-433.

Kremer, B., Kazmerczak, J., Stal, L.J., 2008. Calcium carbonate precipitation in cyanobacterial mats from sandy flats of the North Sea. Geobiology 6, 46-56.

Li, H., Devaux, P., 2001. Enhancement of microspore culture efficiency of recalcitrant barley genotypes. Plant Cell Rep. 20, 475-481.

Long, X., Tang, R., Fang, Z., Xie, C., Li, Y., Xian, G., 2017. The roles of loosely-bound and tightly-bound extracellular polymer substances in enhanced biological phosphorus removal. Chemosphere 189, 679-688.

Ludwig, R., Al-Horani, F.A., De Beer, D., Jonkers, H.M., 2005. Photosynthesis-controlled calcification in a hypersaline microbial mat. Limnol. Oceanogr. 50, 1836-1843.

Maisano, L., Cuadrado, D.G., Gómez, E.A., 2019. Processes of MISS-formation in a modern siliciclastic tidal flat, Patagonia (Argentina). Sediment. Geol. 381, 1-12.

Monty, C.L.V., 1967. Distribution and structure of recent stromatolitic algal mats, Eastern Andros Island, Bahamas. Ann. Soc. Geol. Belg. 90, B55-B100.

Noffke, N., 2010. Geobiology. Microbial Mats in Sandy Deposits from the Archean Era to Today. Springer-Verlag, Berlin 200 pp.

Noffke, N., Awramik, S.M., 2013. Stromatolites and MISS-differences between relatives. GSA Today 23, 4-9.

Paerl, H.W., Fulton, R.S., Moisander, P.H., Dyble, J., 2001. Harmful freshwater algal blooms, with an emphasis on cyanobacteria. Sci. World J. 1, 76-113.

Pan, J., Perillo, V.L., Cuadrado, D.G., 2019. Quantification of microbial mat response to physical disruption in siliciclastic sediments. Estuar. Coast. Shelf Sci. 230. https:// doi.org/10.1016/j.ecss.2019.106434.
Pentecost, A., Bauld, J., 1988. Nucleation of calcite on the sheaths of cyanobacteria using a simple diffusion cell. Geomicrobiol J. 6, 129-135.

Perillo, V.L., Maisano, L., Martínez, A.M., Quijada, I.E., Cuadrado, D.G., 2019. Microbial mat contribution to the formation of an evaporitic environment in a temperate-latitude ecosystem. J. Hydrol. 575, 105-114.

Reid, R.P., Visscher, P.T., Decho, A.W., Stolz, J.F., Bebout, B.M., Dupraz, C., Steppe, T.F., 2000. The role of microbes in accretion, lamination and early lithification of modern marine stromatolites. Nature 406, 989-992.

Riding, R., 2000. Microbial carbonates: the geological record of calcified bacterial-algal mats and biofilms. Sedimentology 47, 179-214.

Riding, R., 2011a. Microbialites, stromatolites, and thrombolites. In: Reitner, J., Thiel, V. (Eds.), Encyclopedia of Geobiology. Springer, Dordrecht, pp. 635-654.

Riding, R., 2011b. The nature of stromatolites: 3,500 million years of history and a century of research. In: Reitner, J., Arp, G., Quéric, N.V. (Eds.), Advances in Stromatolite Geobiology. Lecture Notes in Earth Sciences 131. Springer-Verlag Berlin, pp. 29-74.

Riege, H., Gerdes, G., Krumbein, W.E., 1991. Contribution of heterotrophic bacteria to the formation of $\mathrm{CaCO}_{3}$-aggregates in hypersaline microbial mats. Kiel. Meeresforsch. 8, $168-172$.

Shinn, E.A., Lloyd, R.M., Ginsburg, R.N., 1969. Anatomy of a modern carbonate tidal-flat, Andros Island, Bahamas. J. Sediment. Petrol. 39, 1202-1228.

Sim, M.S., Liang, B., Petroff, A.P., Evans, A., Klepac-Ceraj, V., Flannery, D.T., Walter, M.R., Bosak, T., 2012. Oxygen-dependent morphogenesis of modern clumped photosynthetic mats and implications for the Archean stromatolite record. Geosciences 2, 235-259.

Stal, L.J., 2012. Cyanobacterial mats and stromatolites. In: Whitton, B.A. (Ed.), Ecology of Cyanobacteria II: Their Diversity in Space and Time. Springer, Dordrecht, pp. 65-125.

Stempels Bautista, C., 2019. Ondas de tormenta en la zona costera de Paso Seco. Buenos Aires. Argentina. BSc Thesis. Universidad Nacional del, Sur (Argentina) $60 \mathrm{pp}$.

Strickland, J.D., Parsons, T.R, 1972. A Practical Handbook of Seawater Analysis.

Strohmenger, C.J., Shebl, H., Al-Mansoori, A., Al-Mehsin, K., Al-Jeelani, O., Al-Hosani, I., AlShamry, A., Al-Baker, S., 2011. Facies stacking patterns in a modern arid environment: a case study of the Abu Dhabi sabkha in the vicinity of Al Rafeq Island, United Arab Emirates. In: Kendall, C.G.St.C., Alsharhan, A.S. (Eds.), Quaternary Carbonate And Evaporite Sedimentary Facies and Their Ancient Analogues: A Tribute to Douglas James Shearman. International Association of Sedimentologists. Special Publication 43. Wiley-Blackwell, Chichester, pp. 149-183.

Thompson, J.D., Higgins, D.G., Gibson, T.J., 1994. CLUSTAL W: improving the sensitivity of progressive multiple sequence alignment through sequence weighting, position-specific gap penalties and weight matrix choice. Nucleic Acids Res. 22, 4673-4680.

Usiglio, M.J., 1849. Etudes sur la composition de l'eau de la Mediterranee et sur l'exploitation des sels qu'elle contient. Ann. Chim. Phys. 3 (27), 172-191.

Visscher, P.T., Stolz, J.F., 2005. Microbial mats as bioreactors: populations, processes, and products. Palaeogeogr. Palaeoclimatol. Palaeoecol. 219, 87-100. 